\title{
Choroby układu sercowo-naczyniowego u pacjenta z zatorem tętnicy siatkówki
}

\section{Cardiovascular diseases in a patient with a retinal artery occlusion}

\author{
Paweł Wałek ${ }^{2}$, Joanna Roskal-Wałek ${ }^{1}$, Janusz Sielski ${ }^{2,4}$, Magdalena Gierada ${ }^{1}$, \\ Jerzy Mackiewicz ${ }^{3}$, Beata Wożakowska-Kapłon ${ }^{2,4}$ \\ ${ }^{1}$ Klinika Okulistyki Wojewódzkiego Szpitala Zespolonego w Kielcach \\ ${ }^{2}$ Świętokrzyskie Centrum Kardiologii Wojewódzkiego Szpitala Zespolonego w Kielcach \\ ${ }^{3}$ Klinika Chirurgii Siatkówki i Ciała Szklistego Uniwersytetu Medycznego w Lublinie \\ ${ }^{4}$ Wydział Lekarski Nauk o Zdrowiu Uniwersytetu Jana Kochanowskiego w Kielcach
}

\section{Streszczenie}

Zator tętnicy siatkówki może być pierwszym objawem chorób układu sercowo-naczyniowego. Do najczęstszych przyczyn zatoru tętnicy siatkówki należą miażdżyca tętnic szyjnych i patologie zastawek serca. Zator tętnicy siatkówki może być również pierwszym objawem infekcyjnego zapalenia wsierdzia, śluzaka przedsionka, migotania przedsionków czy olbrzymiokomórkowego zapalenia tętnic. Pacjenci po incydencie zatoru tętnicy siatkówki mają krótszą przewidywaną długość życia, większe ryzyko udaru mózgu czy ostrego zespołu wieńcowego. W pracy opisano przyczyny sercowo-naczyniowe zatoru tętnicy siatkówki, szczególną uwagę poświęcono odpowiedniej diagnostyce, dzięki której możliwa jest identyfikacja chorób układu sercowo-naczyniowego i ich właściwe leczenie, co wiążę się z poprawą rokowania w aspekcie przeżycia w tej grupie chorych.

Słowa kluczowe: zator tętnicy siatkówki, miażdżyca, ostry zespół wieńcowy, udar mózgu, infekcyjne zapalenie wsierdzia, migotanie przedsionków

Folia Cardiologica 2016; 11, 2: 134-139

\section{Wstęp}

Zamknięcie naczynia tętniczego siatkówki (RAO, retinal artery occlusion) zaliczane jest do stanów nagłych w okulistyce, wymagających pilnego leczenia i poszerzonej diagnostyki. Ryzyko wystąpienia RAO u osób powyżej 50. roku życia ocenia się na około 3\% w obserwacji 10-letniej, ale podkreśla się, że wynik ten może być niedoszacowany [1]. Zator tętnicy siatkówki może być pierwszym objawem choroby ogólnoustrojowej. Do chorób, które najczęściej doprowadzają do zaburzeń krążenia w łożysku tętniczym siatkówki należą: miażdżyca tętnic szyjnych i aorty, patologie zastawki mitralnej i aortalnej, infekcyjne zapalenia wsierdzia (IE, infective endocarditis) czy olbrzymiokomórkowe zapalenie tętnicy skroniowej (GCA, giant cell arteritis). Dokładna ocena pacjentów z RAO pozwala na rozpoznanie niezdiagnozowanych chorób współistniejących, może ułatwić decyzję o wdrożeniu odpowiedniego leczenia, a tym samym poprawić rokowanie, nie tylko w aspekcie kolejnego incydentu zatorowego, ale także w aspekcie przeżycia tych chorych. 
Przyczyny i patogeneza zatoru tętnicy siatówki

Unaczynienie oka pochodzi od tętnicy ocznej, która jest pierwszą gałęzią tętnicy szyjnej wewnętrznej. Tętnica środkowa siatkówki, będąca gałęzią tętnicy ocznej, zaopatruje wewnętrzne warstwy siatkówki. Zewnętrzne warstwy siatkówki są zaopatrywane przez tętnice rzęskowe, które również pochodzą od tętnicy ocznej. Podstawą prawidłowego funkcjonowania siatkówki jest odpowiednie ukrwienie jej zewnętrznych i wewnętrznych warstw.

Ze względu na etiopatogenezę wyróżnia się niezapalne RAO (non-arteritic retinal artery occlusion) oraz zapalne RAO (arteritic retinal artery occlusion). Niezapalne RAO stanowią znaczącą większość przypadków RAO i zaliczane są do nich RAO spowodowane materiałem zatorowym pochodzącym z blaszek miażdżycowych tętnic szyjnych i aorty, ze zmian zwyrodnieniowych lub wegetacji bakteryjnych umiejscowionych na płatkach zastawek serca, skrzeplin zlokalizowanych w jamach serca lub na powierzchni guzów wewnątrzsercowych, może być także skutkiem zatoru skrzyżowanego u pacjentów z przetrwałym otworem owalnym lub przejściowego skurczu tętniczek unaczyniających siatkówkę. Materiał zatorowy może również powstać w trakcie zabiegów wewnątrznaczyniowych lub w przebiegu zaburzeń hematologicznych. W około 15\% przypadków niezapalnych RAO dochodzi jedynie do przejściowego zaniewidzenia (amaurosis fugax).

Zatory mogą się lokalizować w tętnicy środkowej siatkówki (CRAO, central retinal artery occlusion) lub jej gałęziach (BRAO, branch retinal artery occlusion) i moga być pojedyncze lub mnogie. Obraz kliniczny RAO zależy od naczynia, które zostaje zamknięte przez materiał zatorowy. Zator tętnicy środkowej siatkówki objawia się jako nagła, bezbolesna utrata wzroku, a BRAO może pozostać bezobjawowy lub skutkować jedynie subtelnym obniżeniem ostrości wzroku czy sektorowym ubytkiem w polu widzenia.

Do czynników ryzyka RAO zalicza się: nadciśnienie tętnicze, chorobę niedokrwienną serca, udar mózgu, nikotynizm, obturacyjny bezdech senny, obecność blaszki miażdżycowej w tętnicach szyjnych i aorcie, podwyższone stężenia cholesterolu frakcji LDL (LDL, low-density lipoprotein), lipoproteiny (a), fibrynogenu, homocysteiny, niedobór białka C i S, antytrombiny III, obecność przeciwciał antyfosfolipidowych, mutacji genu protrombiny G20210A, a także anemię sierpowatokrwinkową oraz migrenę. Wśród okulistycznych czynników ryzyka wymienia się podwyższone ciśnienie wewnątrzgałkowe, druzy tarczy nerwu wzrokowego oraz malformacje naczyniowe $[3,5]$.

Wygląd materiału zatorowego może być pomocny w ustaleniu jego pochodzenia. Pod względem morfologicznym wyróżnia się 3 typy zatorów: cholesterolowe, fibrynowo-płytkowe i wapniowe. Do najczęściej obserwowanych (ok.
75\%) należą zatory cholesterolowe, zwane płytkami Hollenhorsta. Zatory te wyglądają jak małe, żółte, hiperrefleksyjne płytki, najczęściej lokalizują się w rozwidleniach gałęzi tętnicy środkowej siatkówki, są bezobjawowe lub powodują przejściowe zaniewidzenie. Źródłem płytek Hollenhorsta są blaszki miażdżycowe. Zatory fibrynowo-płytkowe stanowia około 15\% przypadków, są bladozielone, często długie i mnogie, mogą wywołać zarówno przejściowe, jak i trwałe zamknięcie naczynia, pochodzą z blaszek miażdżycowych oraz skrzeplin powstających w jamach serca lub na zastawkach. Zatory wapniowe (ok. 10\%) wyglądają jak pojedyncze białe, nieodbijające światła płytki, ze względu na swój rozmiar i budowę często lokalizują się w proksymalnym odcinku tętnicy środkowej siatkówki lub na tarczy nerwu wzrokowego. Zatory te najczęściej pochodzą ze zwapniałych blaszek miażdżycowych lub zwapnień zlokalizowanych na zastawkach serca. Zatory wapniowe w większości powodują trwałe zamknięcie naczynia [4]. Rozróżnienie poszczególnych typów zatorów pod kątem materiału, z jakiego są zbudowane w praktyce jest bardzo trudne, co sprawia, że subiektywne oceny badających różnią się między sobą. Materiał zatorowy o dużych rozmiarach, który dostał się do tętnicy ocznej najczęściej umiejscawia się na wysokości blaszki sitowej, gdzie tętnica jest najwęższa. W tej lokalizacji, choć materiał zatorowy jest niewidoczny w badaniu dna oka, prowadzi do uogólnionego niedokrwienia siatkówki.

Najczęstszym źródłem materiału zatorowego w RAO są blaszki miażdżycowe tętnic szyjnych [3]. W tym przypadku niedokrwienie siatkówki może być wywołane przez materiał zatorowy, powstać na skutek zmniejszonego przepływu krwi spowodowanego krytyczną stenozą lub zamknięciem tętnicy szyjnej wewnętrznej, czy też być efektem skurczu tętnicy środkowej siatkówki indukowanego serotoniną uwolnioną z płytek krwi zgromadzonych na uszkodzonej blaszce miażdżycowej [6].

Kolejnym ważnym źródłem materiału zatorowego w RAO są zmiany zwyrodnieniowe na płatkach zastawek aortalnej i mitralnej. Zmiany patologiczne na zastawkach u pacjentów z RAO są opisywane w 26-41\% przypadków [3-5]. Najczęściej opisuje się zwapnienia na brzegach płatków lub u ich podstawy (57-70\%) oraz stenozę i niedomykalność zastawek. Prolaps płatka zastawki mitralnej występuje w 4-17\% przypadków [3]. W około 4,3\% przypadków z RAO w badaniu echokardiograficznym przezprzełykowym są opisywane zmiany o charakterze bakteryjnych wegetacji [7]. Charakterystycznym, ale rzadko spotykanym objawem IE sa plamki Rhota - wybroczyny siatkówkowe z białym centrum. Należy podkreślić, że plamki Rhota nie są objawem patognomonicznym IE i mogą występować także w białaczkach, cukrzycy i chorobie Addisona-Biermera [8].

Następnym ważnym źródłem RAO są skrzepliny i guzy wewnątrzsercowe. Skrzepliny mogą powstawać na podłożu zaburzeń kurczliwości ścian lewej komory (LV, left ventricle), 
na powierzchni guzów serca, płatkach zastawek lub w wyniku zaburzeń rytmu serca [3, 5, 9]. Odcinkowe zaburzenia kurczliwości w szczególności tętniaki pozawałowe, kardiomiopatia rozstrzeniowa, kardiomiopatia połogowa czy niescalenie mięśnia LV były opisywane jako źródła materiału zatorowego w RAO [10, 11]. Rzadkim, choć najczęściej opisywanym, guzem serca powodującym zatory obwodowe, w tym RAO, jest śluzak [9, 12]. Opisywano także przypadki RAO wywołane obecnością włókniaka brodawkowatego lokalizującego się głównie na płatkach zastawek aortalnej lub mitralnej $[13,14]$.

Inną przyczyną RAO, opisywaną głównie u młodszych pacjentów, jest zatorowość skrzyżowana w przebiegu przetrwałego otworu owalnego (PFO, patent foramen ovale) $[15,16]$.

Częstość występowania RAO u pacjentów z migotaniem przedsionków (AF, atrial fibrillation) ocenia się na 2,4-2,6\% [17, 18]. Choć odsetek pacjentów jest niewielki, to - biorąc pod uwagę częstość występowania AF w populacji ogólnej - bezwzględna liczba pacjentów może być istotna. Anderson i wsp. [18] próbowali tłumaczyć, dlaczego u pacjentów z AF rzadziej niż w miażdżycy tętnic szyjnych diagnozuje się RAO. Ich zdaniem materiał zatorowy, który powstaje w przebiegu AF jest większy, przez co trudniej dostaje się do tętnicy ocznej, natomiast materiał zatorowy uwolniony z blaszek miażdżycowych tętnic szyjnych jest zazwyczaj małych rozmiarów i może łatwo trafić do tętnicy ocznej, powodując objawy zaburzeń widzenia, a trafiając do łożyska naczyń mózgowych - obraz niemych udarów mózgu. Ma to potwierdzenie w badaniach, które dotyczyły pacjentów z udarem lub przejściowym niedokrwieniem mózgu (TIA, transient ischaemic attack) - zauważono, że materiał zatorowy pochodzący z tętnic szyjnych częściej powodował TIA, a pacjenci z AF mieli częściej dłużej trwające TIA lub udary mózgu o cięższym przebiegu [18].

Z przyczyn pozakardiologicznych, ale ważnych należy wspomnieć o chorobach autoimmunologicznych. U podłoża RAO może leżeć GCA. Ocenia się, że GCA odpowiada za około 4,5\% przypadków CRAO. Z innych chorób autoimmunologicznych trzeba wymienić ziarniniakowatość Wegenera, zespół antyfosfolipidowy, toczeń rumieniowaty układowy, zespół Churga-Strauss, guzkowe zapalnie tętnic, choroba Takayasu, choroba Behçeta [19-25]. Do chorób nieautoimmunologicznych, które w rzadkich przypadkach mogą powodować RAO zalicza się ludzki wirus nabytego niedoboru odporności (AIDS, human immunodeficiency virus), niedokrwistość sierpowatokrwinkową, migrenę, toksoplazmozę, wirus opryszczki czy odczyny po szczepieniu przeciw ospie. Zaburzenia hematologiczne prowadzące do stanu nadkrzepliwości mogą także być przyczyną RAO. Z zaburzeń tych najczęściej wymienia się niedobory białka C i S, obecność antykoagulantu toczniowego, przeciwciał antyfosfolipidowych, czynnika $\mathrm{V}$ Leiden, mutacji genu protrombiny G20210A czy hiperhomocysteinemię. Istnieją także doniesienia o wpływie leków antykoncepcyjnych na ryzyko wystąpienia RAO [26].

\section{Diagnostyka zatoru tętnicy siatkówki}

Zaleca się, aby pacjenci z RAO, szczególnie ci z widocznym materiałem zatorowym, byli szybko i wnikliwie diagnozowani w celu wykluczenia kardiologicznych przyczyn zatorowości. U pacjenta z RAO należy zebrać dokładny wywiad pod kątem objawów chorób mogących odpowiadać za incydent RAO, a także czynników ryzyka sercowo-naczyniowego. U pacjentów młodych należy zwrócić szczególną uwagę na wywiad rodzinny wczesnej choroby układu sercowo-naczyniowego (CVD, cardiovascular disease). Badanie przedmiotowe ukierunkowane na poszukiwanie sercowo-naczyniowych przyczyn RAO powinno obejmować osłuchiwanie tętnic szyjnych, poszukiwanie szmerów serca, ocenę obecności tętna na tętnicach obwodowych, ocenę płytki paznokciowej pod kątem obecności materiału zatorowego, pomiar ciśnienia tętniczego na obu ramionach. Podczas osłuchiwania tętnic szyjnych należy pamiętać, że krytyczne zwężenie może nie powodować szmeru z powodu zbyt małego przepływu krwi przez zwężone naczynie.

Badaniem podstawowym, które należy przeprowadzić u pacjenta z RAO jest ultrasonografia (USG) tętnic szyjnych z oceną metodą Dopplera. W znaczącej większości epizodów zaniewidzenia materiał zatorowy pochodzi z nieistotnej hemodynamicznie blaszki miażdżycowej, więc niestwierdzenie w badaniu obrazowym obecności istotnego zwężenia nie wyklucza obecności blaszki miażdżycowej jako źródła materiału zatorowego. Leisser i wsp. [7] ocenili prawdopodobieństwo wystąpienia RAO w zależności od lokalizacji blaszki miażdżycowej w tętnicy szyjnej. Z badań tych wynika, że największe prawdopodobieństwo RAO występuje w przypadku lokalizacji blaszki miażdżycowej w odcinku tętnicy szyjnej wewnętrznej przebiegającym w bruździe kości klinowej oraz przez zatokę jamistą w bezpośrednim sąsiedztwie odejścia tętnicy ocznej [7]. Podkreśla się, że ocena USG dotyczy jedynie niewielkiego fragmentu tętnic szyjnych w okolicy rozwidlenia tętnicy szyjnej wspólnej na wewnętrzną i zewnętrzną [3]. Ważny jest także fakt, że rozdzielczość aparatów ultrasonograficznych jest często niewystarczająca do wykrycia małej, miękkiej blaszki miażdżycowej. Wynika z tego, że brak obecności blaszek miażdżycowych w badaniu USG nie wyklucza ich obecności jako potencjalnego źródła materiału zatorowego.

W spoczynkowych 12-odprowadzeniowym badaniu elektrokardiograficznym (EKG) poszukuje się zaburzeń rytmu serca, cech przerostu mięśnia sercowego, przeciążenia objętościowego jamy LV, przerostu prawej komory (RV, right ventricle), przebytego zawału serca, tętniaka LV oraz cech poszerzenia jam serca. Badanie elektrokar- 
diograficzne metodą Holtera jest nastawione głównie na poszukiwanie zaburzeń rytmu serca zwiększających ryzyko tworzenia skrzeplin w jamach serca, czyli AF i trzepotania przedsionków.

Podstawowym i łatwo dostępnym badaniem wykonywanym w celu oceny kardiologicznych przyczyn RAO jest echokardiografia przezklatkowa (TTE, transthoracic echocardiography). W przypadkach wątpliwych lub wymagających bardziej szczegółowej oceny należy przeprowadzić badanie metodą echokardiografii przezprzełykowej (TEE, transesophagal echocardiography), które pozwala lepiej ocenić zastawki, przecieki wewnątrzsercowe, w tym PFO, oraz obecność skrzeplin [27].

Celowość wykonywania badania echokardiograficznego serca potwierdzają wyniki badań Mouradiana i wsp. [28]. Prospektywne badanie objęło grupe 73 pacjentów, 34 z nich miało bezobjawowe zatory cholesterolowe, 28 - przemijające zaniewidzenie, 11 - CRAO lub BRAO. Stwierdzono zmiany w badaniu echokardiograficznym u 16 z 73 chorych, to jest 21,9\%, w tym 8 prezentowało AF lub zmiany w tętnicy szyjnej ze stenozą powyżej 50\%. Ośmiu chorych miało zmiany wykryte tylko w badaniu echokardiograficznym. Do najczęściej stwierdzonych zmian należały blaszki miażdżycowe powyżej $4 \mathrm{~mm}$, położone w proksymalnym odcinku aorty i frakcja wyrzutowa mniejsza niż 30\%. Badanie echokardiografii przezprzełykowej było szczególnie pomocne w odnajdywaniu blaszek miażdżycowych aorty [28].

\section{Rokowanie}

Z badań epidemiologicznych wynika, że czynniki ryzyka RAO pokrywają się z czynnikami ryzyka sercowo-naczyniowego [5, 29-33]. W wielu badaniach podkreśla się rolę palenia tytoniu jako jednego z najbardziej obciążających czynników ryzyka. Wang i wsp. [34] przeanalizowali wyniki 2 badań dotyczących oceny ryzyka zgonu u pacjentów z RAO. Łącznie w badaniach wzięło udział 8580 osób w wieku 43-97 lat, u których oceniono dno oka pod kątem obecności materiału zatorowego w naczyniach tętniczych siatkówki. Ryzyko zgonu z jakiejkolwiek przyczyny u pacjentów z RA0 było 1,3 raza większe, natomiast ryzyko zgonu z powodu udaru mózgu -2 razy wyższe. W tej analizie nie wykazano zwiększonego ryzyka zgonu z przyczyn sercowo-naczyniowych [34]. Bruno i wsp. [35] poddali obserwacji 70 pacjentów po RAO i zauważyli, że roczne ryzyko udaru u mężczyzn po RAO jest 10-krotnie wyższe niż w grupie kontrolnej. Podobnie w badaniu Chin i wsp. [36] w obserwowanej grupie 26 pacjentów w ciągu 7 miesięcy od incydentu RAO 4 (15\%) doznało udaru niedokrwiennego mózgu. Chang i wsp. [37] przeanalizowali dane ze wszystkich zarejestrowanych hospitalizacji na Taiwanie w latach 1999-2006. Łącznie baza zawierała 24 miliony zapisów. W drodze losowania wybrano 1 milion zapisów. Wyselekcjonowano z nich te, w których powodem hospitalizacji był RAO. Liczba tych hospitalizacji wynosiła 464. Następnie pacjentów tych poddano analizie pod kątem epizodu udarowego w kolejnych 3 latach od rozpoznania RAO. Wyniki pokazały 2-krotnie (współczynnik ryzyka [HR, hazard ratio] 2,16) większe ryzyko udaru mózgu w obserwacji 3-letniej u pacjentów po RAO, przy czym największe ryzyko występowało w pierwszych 30 dniach od RAO (HR 9,46). Zauważono, że największe ryzyko występuje u pacjentów poniżej 60. roku życia [37]. Ta sama grupa badaczy przeanalizowała tę samą baze danych, ale gromadzonych w latach 1999-2008, pod kątem ryzyka wystąpienia ostrego zespołu wieńcowego (ACS, acute coronary syndromes) u pacjentów z RAO. Oceniono, że ryzyko ACS było 1,72 raza większe w grupie pacjentów z RAO [38].

Kolejnym ważnym zagadnieniem jest ocena ryzyka udaru mózgu u pacjentów z RAO i AF. Christiansen i wsp. [17] ocenili w retrospektywnym badaniu pacjentów z rejestru AF, zarejestrowanych w latach 1997-2008. Rejestr obejmował 87202 pacjentów z niezastawkowym AF, z których 224 (0,26\%) miało rozpoznane RAO. Pacjenci z AF, u których rozpoznano RAO mieli ryzyko wystąpienia udaru mózgu około 40\% większe niż pacjenci bez RAO. Christiansen i wsp. zaproponowali, aby epizod RAO włączyć do oceny skali $\mathrm{CHA}_{2} \mathrm{DS}_{2}$-VASC jako składową choroby naczyniowej, co daje dodatkowy 1 punkt. Aktualnie nie ma zaleceń, jak interpretować epizod RAO w ocenie według skali $\mathrm{CHA}_{2} \mathrm{DS}_{2}$-VASc, czy jako incydent zakrzepowo-zatorowy, czyli równoważny z przebytym udarem mózgu, i przydzielić mu 2 punkty, czy raczej jako chorobę naczyniową i przydzielić 1 punkt. Analiza Christiansena i wsp. oceniła HR RAO dla udaru mózgu w analizie wieloczynnikowej na 1,39 (95-proc. przedział ufności [Cl, confidence interval] 1,08-1,79), co w porównaniu z HR poszczególnych składowych skali $\mathrm{CHA}_{2} \mathrm{DS}_{2}$-VASC plasuje RAO bliżej choroby naczyniowej (HR 1,52) niż udaru mózgu (HR 2,24). Reasumując, u pacjentów z AF, którzy doświadczyli RAO zasadne wydaje się włączenie doustnego antykoagulantu w celu prewencji udaru mózgu.

\section{Podsumowanie}

Związek miedzy wystąpieniem RAO a obecnością CVD jest dobrze znany. Czynniki ryzyka wystąpienia incydentu RAO pokrywają się z czynnikami ryzyka CVD. Nadciśnienie tętnicze, cukrzyca, hiperlipidemia, choroby tętnic szyjnych, choroby naczyń wieńcowych, TIA/udar mózgu, palenie tytoniu są opisywane częściej u pacjentów z RAO [1-8]. Dokładna ocena ryzyka sercowo-naczyniowego u pacjentów z RAO ma istotne implikacje kliniczne. Zamknięcie naczyń siatkówki ma często przyczyny systemowe, których diagnoza i leczenie ma wpływ nie tylko na postępowanie okulistyczne, ale także na rokowanie co do życia pacjentów. 
Określenie czynników ryzyka sercowo-naczyniowego z pełnym badaniem kardiologicznym umożliwia identyfikację chorych pozostających do tej pory w grupie niezdiagnozowanych, wdrożenie odpowiedniego leczenia, a tym samym poprawę rokowania nie tylko w aspekcie kolejnego incydentu sercowo-naczyniowego, ale także w zakresie przeżycia tych chorych. U pacjentów z RAO bez czynników ryzyka sercowo-naczyniowego z przyczyn kardiologicznych należy ze szczególną starannością poszukiwać PFO lub guzów serca.

\section{Konflikt interesów}

Autorzy deklarują brak konfliktu interesów.

\section{Abstract}

Retinal artery occlusion may be the first symptom of diseases of the cardiovascular system. The most common causes of retinal artery embolism include carotid atherosclerosis and heart valve pathologies. Retinal artery occlusion may be the first symptom of infective endocarditis, atrial myxoma, atrial fibrillation, or giant cell arteritis. Patients after the incident of retinal artery embolism have a shorter life expectancy, higher risk of stroke or acute coronary syndrome. This paper describes cardiovascular causes of retinal artery occlusion; particular attention was given to proper diagnosis, through which it is possible to identify cardiovascular disorders, their proper treatment, which is associated with improved outcome in terms of survival in this group of patients.

Key words: retinal artery occlusion, atherosclerosis, acute coronary syndrome, stroke, infectious endocarditis, atrial fibrillation

Folia Cardiologica 2016; 11, 2: 134-139

\section{Piśmiennictwo}

1. Cugati S., Wang J.J., Rochtchina E., Mitchell P. Ten-year incidence of retinal emboli in an older population. Stroke 2006; 37: 908-910.

2. Cheung N., Lim L., Wang J.J. i wsp. Prevalence and risk factors of retinal arteriolar emboli: the Singapore Malay Eye Study. Am. J. Ophthalmol. 2008; 146: 620-624.

3. Hayreh S.S., Podhajsky P.A., Zimmerman M.B. Retinal artery occlusion: associated systemic and ophthalmic abnormalities. Ophthalmology 2009; 116: 1928-1936.

4. Arruga J., Sanders M.D. Ophthalmologic findings in 70 patients with evidence of retinal embolism. Ophthalmology 1982; 89: 1336-1347.

5. Schmidt D., Hetzel A., Geibel-Zehender A., Schulte-Mönting J. Systemic diseases in non-inflammatory branch and central retinal artery occlusion - an overview of 416 patients. Eur. J. Med. Res. 2007; 12: 595-603.

6. Hayreh S.S., Piegors D.J., Heistad D.D. Serotonin-induced constriction of ocular arteries in atherosclerotic monkeys. Implications for ischemic disorders of the retina and optic nerve head. Arch. Ophthalmol. 1997; 115: 220-228.

7. Leisser C., Kaufmann T.A., Feltgen N. i wsp. Distribution of internal carotid artery plaque locations among patients with central retinal artery occlusion in the Eagle study population. Graefes Arch. Clin. Exp. Ophthalmol. 2015; 253: 1227-1230.

8. Roth M. Über Netzhautaffectionenbei Wundfiebern. I. Die embolische Panophthalmitis. Deutsche Zeitschrift für Chirurgie 1872; 1: 471-484.

9. Schmidt D., Hetzel A., Geibel-Zehender A. Retinal arterial occlusion due to embolism of suspected cardiac tumors - report on two patients and review of the topic. Eur. J. Med. Res. 2005; 10: 296-304.
10. Liakakos T.M., Daskalaki M., Sfakianoudis K. i wsp. Permanent unilateral blindness associated with peripartum cardiomyopathy. Hippokratia 2009; 13: 58-60.

11. Jin-Poi T., Shatriah I., Ng S.L. i wsp. Noncompaction cardiomyopathy manifesting as retinal artery occlusion. JAMA Ophthalmol. 2013; 131: 263-265.

12. Yu Y., Zhu Y., Dong A., Su Z. Retinal artery occlusion as the manifestation of left atrial myxoma: a case report. BMC Ophthalmol. 2014; 14: 164.

13. Ergun K., Golbasi Z., Cagli K. i wsp. A rare cause of sudden vision loss in a young male: papillary fibroelastoma of the aortic valve. Echocardiography 2007; 24: 425-429.

14. Zamora R.L., Adelberg D.A., Berger A.S. i wsp. Branch retinal artery occlusion caused by a mitral valve papillary fibroelastoma. Am. J. Ophthalmol. 1995; 119: 325-329.

15. Hayashi K., Iguchi Y., Kimura K. i wsp. Paradoxical brain embolism as a cause of central retinal artery occlusion: a case report. J. Neuroimaging 2007; 17: 255-257.

16. Shoeibi N., Poorzand H., Abrishami M. Branch retinal artery occlusion in a patient with patent foramen ovale. J. Ophthalmic Vis. Res. 2013; 8: 58-61.

17. Christiansen C.B., Lip G.Y., Lamberts M. i wsp. Retinal vein and artery occlusions: a risk factor for stroke in atrial fibrillation. J. Thromb. Haemost. 2013; 11: 1485-1492.

18. Anderson D.C., Kappelle L.J., Eliasziw M. i wsp. Occurrence of hemispheric and retinal ischemia in atrial fibrillation compared with carotid stenosis. Stroke 2002; 33: 1963-1967. 
19. Costello F., Gilberg S., Karsh J. i wsp. Bilateral simultaneous central retinal artery occlusions in Wegener granulomatosis. J. Neuroophthalmol. 2005; 25: 29-32.

20. Bisighini S., Zerilli-Zavgorodni T. Branch retinal artery occlusion secondary to antiphospholipid syndrome. Optom. Vis. Sci. 2012; 89: e78-e84.

21. Hua L., Patel K., Corbett J.J. Bilateral central retinal artery occlusion in a patient with systemic lupus erythematosus. J. Stroke Cerebrovasc. Dis. 2015; 24: e139-141.

22. Kamata Y., Hashizume K., Kaneko M., Kurosaka D. A case of Churg-Strauss syndrome and central retinal artery occlusion with good visual recovery. Indian J. Ophthalmol. 2013; 61: 178-179.

23. Thakker A.D., Gajre M., Khubchandani R. i wsp. Bilateral central retinal artery occlusion: an unusual presentation of polyarteritis nodosa. Indian J. Pediatr. 2014; 81: 1401-1402.

24. Kaushik S., Gupta A., Gupta V. i wsp. Retinal arterial occlusion in Takayasu's arteritis. Indian J. Ophthalmol. 2005; 53: 194-196.

25. Yahia S.B., Kahloun R., Jelliti B., Khairallah M. Branch retinal artery occlusion associated with Behçet disease. Ocul. Immunol. Inflamm. 2011; 19: 293-295.

26. Varma D.D., Cugati S., Lee A.W., Chen C.S. A review of central retinal artery occlusion: clinical presentation and management. Eye (Lond). 2013; 27: 688-697.

27. Inatomi Y., Hino H., Hashimoto Y. i wsp. Transesophageal echocardiography for detection of cardiac diseases in patients with retinal artery occlusion. Intern. Med. 2001; 40: 475-478.

28. Mouradian M., Wijman C.A., Tomasian D. i wsp. Echocardiographic findings of patients with retinal ischemia or embolism. J. Neuroimaging 2002; 12: 219-223.
29. Klein R., Klein B.E., Jensen S.C. i wsp. Retinal emboli and stroke: the Beaver Dam Eye Study. Arch. Ophthalmol. 1999; 117: 1063-1068.

30. Wong T.Y., Klein R. Retinal arteriolar emboli: epidemiology and risk of stroke. Curr. Opin. Ophthalmol. 2002; 13: 142-146.

31. Klein R., Klein B.E., Moss S.E., Meuer S.M. Retinal emboli and cardiovascular disease: the Beaver Dam Eye Study. Arch. Ophthalmol. 2003; 121: 1446-1451.

32. Weger M., Renner W., Pinter O. i wsp. Role of factor V Leiden andprothrombin 20210A in patients with retinal artery occlusion. Eye 2003; 17: $731-734$.

33. Wong T.Y., Larsen E.K., Klein R. i wsp. Cardiovascular riskfactors for retinal veinocclusionandarteriolaremboli:theAtherosclerosis Riskin Communities \& Cardiovascular Health studies. Ophthalmology 2005; 112: 540-547.

34. Wang J.J., Cugati S., Knudtson M.D. i wsp. Retinal arteriolar emboli and long-term mortality: pooled data analysis from two older populations. Stroke 2006; 37: 1833-1836.

35. Bruno A., Jones W.L., Austin J.K. i wsp. Vascular outcome in men with asymptomatic retinal cholesterol emboli. A cohort study. Ann. Intern. Med. 1995; 122: 249-253.

36. Chin H.S., Yoon J.H., Moon Y.S., Oh J.H. Transthoracic echocardiography and carotid Doppler ultrasound for detection of cardiac and carotid artery disease in patients with acute retinal artery obstruction. Korean J. Ophthalmol. 2004; 18: 148-153.

37. Chang Y.S., Jan R.L., Weng S.F. i wsp. Retinal artery occlusion and the 3-year risk of stroke in Taiwan: a nationwide population-based study. Am. J. Ophthalmol. 2012; 154: 645-652.

38. Chang Y.S., Chu C.C., Weng S.F. i wsp. The risk of acute coronary syndrome after retinal artery occlusion: a population-based cohort study. Br. J. Ophthalmol. 2015; 99: 227-231. 